\title{
Influence of light conditions on the predetermination of foliar characteristics in Betula alleghaniensis Britton
}

\author{
M. Labrecque1, P. Bellefleur ${ }^{2}$, J.P. Simon ${ }^{3}$ and S. Popovich 4 \\ 1 Jardin Botanique de la Ville de Montréal, 4101 est, rue Sherbrooke, Montréal, Qc, H1X 2B2, \\ 2 Faculté de Foresterie et Géodésie, Université Laval, Ste-Foy, Qc, G1K 7P4, \\ 3 Département des Sciences Biologiques, Université de Montréal, Montréal, Qc, H3C 3J7, and \\ 4 Centre de Foresterie des Laurentides, Forêts Canada, C.P. 3800, Ste-Foy, Qc, G1V 4C7, Canada
}

\section{Introduction}

Several studies have shown that the morphology and physiological processes of leaves are largely influenced by light conditions in the environment. However, little is known about the importance of light conditions during the previous year on the development of leaves the following spring. A few researchers have reported contradictory information. Isanogle (1944), Cormack and Gorham (1953) and, more recently, Goulet and Bellefleur (1986) found that light intensity before leaf expansion was not important in determining leaf characteristics and that leaf expression was not predetermined in the bud. Other reports concluded that the anatomical and physiological characteristics of early leaves (preformed in the winter buds, which emerge shortly after bud break) are primarily determined by the light conditions prevailing during the previous growth season (Hansen, 1959; Roy et al., 1986).

The objective of this study was to determine the effect of various light treatments applied during one growth season, on the morphology and chlorophyll content of leaves developing during the following year. The study was conducted with reforestation in mind and takes into account the problem of changes in light conditions which seedlings grown in the nursery for 1 or 2 seasons are subjected to when planted.

\section{Materials and Methods}

During one growth season (n), 50 seedlings of yellow birch (Betula alleghaniensis Britton) $(1+$ 0 ) were grown outdoors in $1 \mathrm{I}$ pots in full sun condition (FSC), while 50 others were shaded so as to receive $25 \%$ of full daylight (SC). Before the beginning of the following growth season $(n+1)$, seedlings from each group were split into 2 lots so as to constitute 4 types of treatments as shown in Table I. Early and late leaf samples were harvested randomly from the seedlings during year $n+1$. Early leaves were taken from the basis of long shoots, 1 and 4 wk after leafing-out. New fully expanded late leaves were harvested twice, early in July and in mid-August. 
Table I. Growth light conditions received by seedlings during previous year $(n)$ and current year $(n+1)$ of investigation.

\begin{tabular}{lll}
\hline Light treatments & Yearn & Year $\mathrm{n}+1$ \\
\hline Treatment 1 & FSC & FSC \\
Treatment 2 & SC & FSC \\
Treatment 3 & FSC & SC \\
Treatment 4 & SC & SC \\
\hline
\end{tabular}

FSC: full sun condition; SC: shade condition ( $25 \%$ full sun).

The following data were compared for each sample: 1) specific leaf area (SLA, mg of dry weight per $\mathrm{cm}^{2}$ ); 2) proportion of leaf tissue (using a stereological procedure similar to that used by Chabot and Chabot (1977)); and 3) chlorophyll content $(a+b)$, expressed on the basis of leaf area and dry weight. All data were subjected to variance analysis, quoted significance levels are at $P \leq 0.05$.

\section{Results}

\section{Leaf structure}

$S L A$ values calculated for early and late leaves which developed during year $n+1$ are given in Table II. They were generally higher for leaves which developed in full sun. However, under each type of experi- mental condition during year $n+1$, a clear influence of the light treatment of the previous year ( $n$ ) was observed. Under the same conditions, SLA values were significantly different for early leaves harvested at the beginning of the season. Leaves which developed on seedlings which were exposed to full sun conditions during year $n$ had proportionally higher values than those grown in shaded conditions during year $n$. Differences exhibited by early leaves subsided a little as the growth season progressed but can still be observed after $4 \mathrm{wk}$ (Table II). In late leaves, the influence of light conditions of the previous year was not observed (Table II).

\section{Leaf anatomy}

Table III summarizes data on anatomical features. The method we used allowed comparison of the percentages of tissue volumes and air spaces in the leaf samples. In early leaves, palisade tissue and, to a greater extent, the volume of air spaces seem to have been most affected by changes in the light conditions. For treatments 1 and 3 (Table 1 ), leaves had proportionally more palisade tissue and fewer air spaces than those subjected to treatments 2 and 4 (Tables I and III). The spongy mesophyll exhibited few variations with respect to the various treatments. A

Table II. Effects of light treatments on specific leaf area $\left(\mathrm{mg}\right.$ of dry weight/ $\mathrm{cm}^{2}$ ) of early and late leaves harvested at different times during the $n+1$ growth season.

\begin{tabular}{|c|c|c|c|c|c|}
\hline \multirow[t]{2}{*}{ Yearn } & \multirow[t]{2}{*}{ Year $n+1$} & \multicolumn{2}{|l|}{ Early leaves } & \multicolumn{2}{|l|}{ Late leaves } \\
\hline & & $\begin{array}{l}1 \text { wk } \\
\text { after leafing-out }\end{array}$ & $\begin{array}{l}4 \text { wk } \\
\text { after leafing-out }\end{array}$ & $\begin{array}{l}\text { harvested } \\
\text { July } 5\end{array}$ & $\begin{array}{l}\text { harvested } \\
\text { Aug. } 19\end{array}$ \\
\hline $\begin{array}{l}\text { FSC } \\
\text { SC } \\
\text { FSC } \\
\text { SC }\end{array}$ & $\begin{array}{l}\text { FSC } \\
\text { FSC } \\
\text { SC } \\
\text { SC }\end{array}$ & $\begin{array}{l}2.85 \mathrm{a} \\
2.42 \mathrm{~b} \\
1.97 \mathrm{c} \\
1.67 \mathrm{~d}\end{array}$ & $\begin{array}{l}5.05 \mathrm{a} \\
4.81 \mathrm{a} \\
3.28 \mathrm{~b} \\
2.86 \mathrm{c}\end{array}$ & $\begin{array}{l}6.11 a \\
6.50 a \\
3.67 b \\
4.40 c\end{array}$ & $\begin{array}{l}6.20 \mathrm{a} \\
6.93 \mathrm{a} \\
4.35 \mathrm{~b} \\
4.56 \mathrm{~b}\end{array}$ \\
\hline
\end{tabular}

Mean values within a column not followed by the same letter are significantly different $(P<0.05)$. 

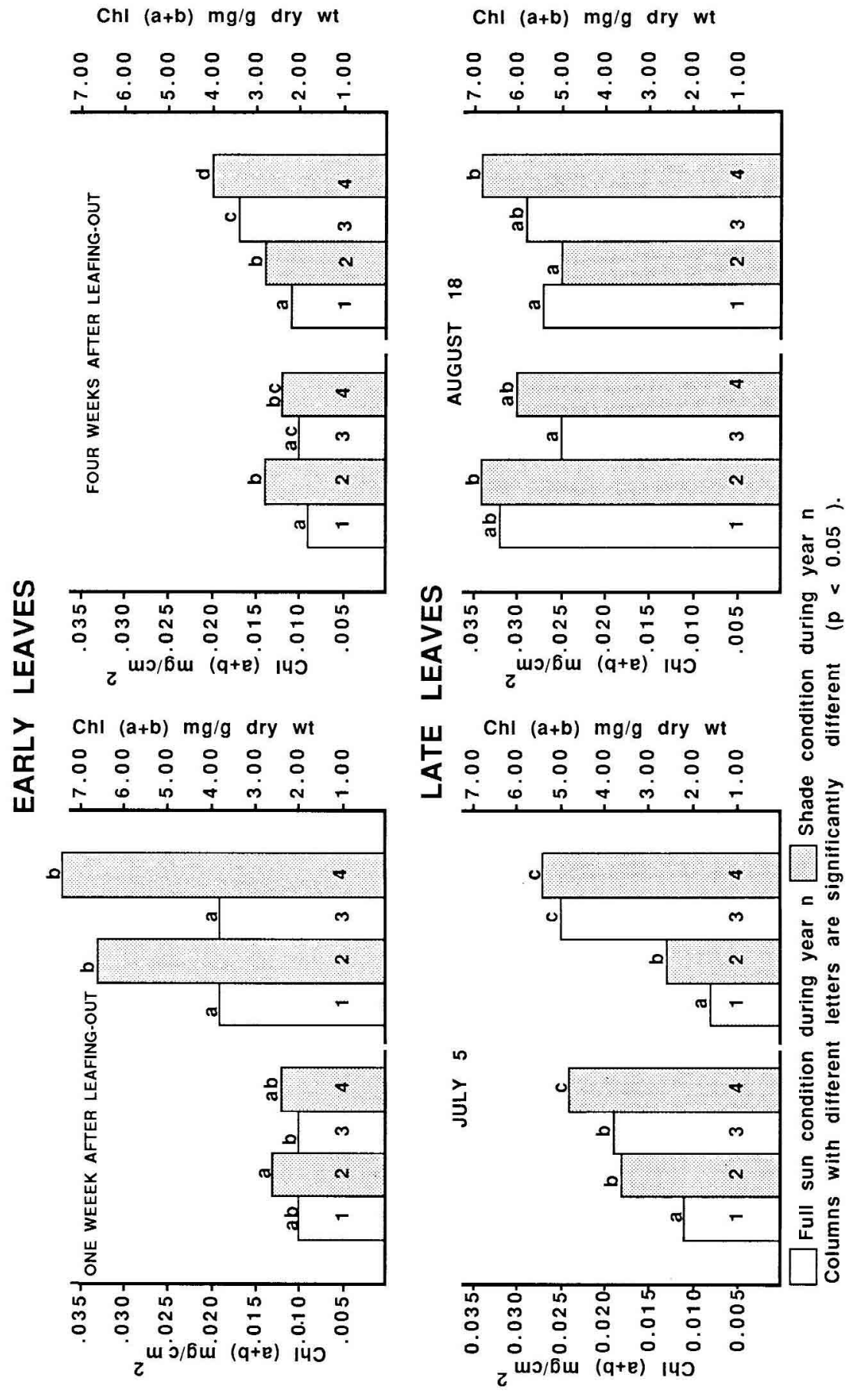

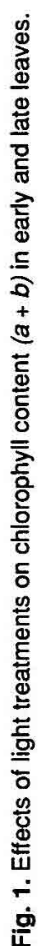


Table III. Effects of light treatments on leaf anatomical characteristics as expressed by percent of tissue volumes.

\begin{tabular}{|c|c|c|c|c|c|c|c|c|c|c|c|c|c|}
\hline \multirow[t]{3}{*}{ Yearn } & \multirow[t]{3}{*}{ Year $n+1$} & \multicolumn{6}{|c|}{ Early leaves } & \multicolumn{6}{|c|}{ Late leaves } \\
\hline & & \multicolumn{3}{|c|}{1 wk after leafing-out } & \multicolumn{3}{|c|}{4 wk after leafing-out } & \multicolumn{3}{|c|}{ harvested July 5} & \multicolumn{3}{|c|}{ harvested Aug. 19} \\
\hline & & p.p. & s.p. & a.s. & p.p. & s.p. & a.s. & p.p. & s.p. & a.s. & p.p. & s.p. & a.s. \\
\hline $\begin{array}{l}\text { FSC } \\
\text { SC } \\
\text { FSC } \\
\text { SC }\end{array}$ & $\begin{array}{l}\text { FSC } \\
\text { FSC } \\
\text { SC } \\
\text { SC }\end{array}$ & $\begin{array}{l}49.6 a \\
43.2 a b \\
37.8 b \\
29.9 c\end{array}$ & $\begin{array}{l}35.5 \mathrm{a} \\
31.8 \mathrm{a} \\
48.1 \mathrm{~b} \\
33.1 \mathrm{c}\end{array}$ & $\begin{array}{l}14.9 \mathrm{a} \\
25.0 \mathrm{~b} \\
14.1 \mathrm{a} \\
37.0 \mathrm{c}\end{array}$ & $\begin{array}{l}44.6 \mathrm{a} \\
35.8 \mathrm{bc} \\
38.9 \mathrm{ab} \\
28.3 \mathrm{c}\end{array}$ & $\begin{array}{l}37.1 a \\
33.3 a \\
28.6 a \\
34.6 a\end{array}$ & $\begin{array}{l}18.3 a \\
30.9 b \\
32.5 b \\
37.1 b\end{array}$ & $\begin{array}{l}47.5 \mathrm{a} \\
44.7 \mathrm{a} \\
33.4 \mathrm{~b} \\
36.0 \mathrm{~b}\end{array}$ & $\begin{array}{l}37.7 \mathrm{a} \\
29.2 \mathrm{ab} \\
25.4 \mathrm{~b} \\
22.4 \mathrm{~b}\end{array}$ & $\begin{array}{l}14.8 \mathrm{a} \\
26.1 \mathrm{~b} \\
41.2 \mathrm{c} \\
41.6 \mathrm{c}\end{array}$ & $\begin{array}{l}44.5 a \\
46.6 a b \\
39.1 a b \\
39.7 b\end{array}$ & $\begin{array}{l}43.8 \mathrm{a} \\
44.3 \mathrm{a} \\
38.8 \mathrm{a} \\
39.8 \mathrm{a}\end{array}$ & $\begin{array}{r}11.7 a \\
9.1 a \\
22.1 b \\
20.5 b\end{array}$ \\
\hline
\end{tabular}

FSC: full sun condition; SC: shade condition.

p.p.: palisade parenchyma; s.p.: spongy parenchyma; a.s.: air spaces.

Percentages within a same column not followed by the same letter are significartly different $(P<0.05)$.

larger proportion of air spaces was also observed in late leaf samples harvested in early July on seedlings of treatments 2 and 4 , but these differences were not observed in leaves harvested in midAugust.

\section{Chlorophyll content}

The chlorophyll content of early leaves was also influenced by the light conditions of year $n$ (Fig. 1). For the 1st harvest of early leaves, the highest values, especially when expressed on the basis of dry weight, were found in leaves harvested on seedlings of treatments 2 and 4 . Differences were less noticeable in early leaves harvested later, and were no longer significant in late leaves.

\section{Discussion}

All analyzed characteristics (structure, anatomy and chlorophyll content) agree and demonstrate that the light conditions to which plants have been exposed have an influence on the development of early leaves the following spring. The consequences on anatomy and, notably, on number of air spaces are evident. Furthermore, this explains why specific leaf area for seedlings grown under shade conditions during year $n$ were not as important. Our results coincide with those of Roy et al. (1986) but are not inconsistent with those of Goulet and Bellefleur (1986) and Cormack and Gorham (1953), since we demonstrate that, as the season progressed, the early leaves were more and more influenced by the light conditions in their new environment. Similarly, late leaves seemed to be influenced only by current year light conditions.

\section{Acknowledgments}

We thank Charıtal Martin for her technical assistance. This project was supported by the GRDE of Canadel.

\section{References}

Chabot B.F. \& Chabot J.F. (1977) Effects of light and temperature on leaf anatomy and photo- 
synthesis in Fragaria vesca. Oecologia (Berlin) 26, 363-377

Cormack R.G.H. \& Gorham A.L. (1953) Effects of exposure to direct sunlight upon the development of leaf structure of two deciduous shrub species. Can. J. Bot. 31, 537-541

Goulet F. \& Bellefleur P. (1986) Leaf morphology plasticity in response to light environment in deciduous tree species and its implication on forest succession. Can. J. For. Res. 16, 1192-1195

Hansen H.C. (1959) Der einfluss des litchtes auf die bildung von licht und schattenblattern der buche, Fagus sylvatica. Physiol. Plant. 12, 545-550

Isanogle I.T. (1944) Effects of controlled shading upon the development of leaf structure in two deciduous tree species. Ecology 25, 404413

Roy J., Thiebaut B. \& Watson M.A. (1986) Physiological and anatomical consequences of morphogenetic polymorphism: leaf response to light intensity in young beech trees (Fagus sytvatica L.). Coll. Int. sur l'Arbre, 9-14 Sept. 1985, Montpellier. Nat. Monsp. H.S. 431-449 